\title{
ARTIKEL
}

\section{Peningkatan Efektivitas Pembangunan Desa Melalui Penyederhanaan Penyaluran Dana Desa}

\section{Increasing The Effectiveness Of Village Development Through The Simplification of Village Funds Disbursement}

\section{a OPEN ACCESS \\ Citation: Ario Bismo, P., \& Eka Sahputra, R. (2021). Peningkatan Efektifitas Pembangunan Desa Melalui Penyederhanaan Penyaluran Dana Desa. Matra Pembaruan. 5(2), 77-88 \\ Received: August 2, 2021 \\ Accepted: October 13, 2021}

Published: November 29, 2021

(๑) The Author(s)

(c) (i) (2) (2)

This work is licensed under a Creative Commons Attribution-NonCommercialShareAlike 4.0 International License.

Kata Kunci: Pembangunan Desa, Dana Desa, penyaluran, UU Desa, pemberdayaan masyarakat

Keywords: village development, village fund, disbursement, village law, community empowerment

\author{
Pandu Ario Bismo (iD) ${ }^{*}$, Riyo Eka Sahputra (iD) 2 \\ ${ }^{1}$ Pusat Studi Pendidikan dan Kebijakan \\ ${ }^{2}$ Komisi Yudisial Republik Indonesia \\ 1Jl. Jeruk Purut No.11, RT.6/RW.3, Cilandak Tim., Kec. Ps. Minggu, Jakarta Selatan \\ 2Jl. Kramat Raya No. 57, Jakarta Pusat
}

$\square$ panduariobismo@gmail.com

\begin{abstract}
Abstrak: Diterbitkannya Undang-Undang Nomor 8 Tahun 2014 tentang Desa telah menumbuhkan optimisme bagi percepatan pembangunan desa di Indonesia. Akan tetapi, permasalahan-permasalahan yang bersifat teknis seperti penyaluran dana desa yang terlambat dari pemerintah daerah, tahapan penyaluran yang membatasi keleluasaan penggunaan dana desa, hingga keterbatasan kapasitas sumber daya manusia pemerintah desa dalam memenuhi tuntutan beban administratif yang tinggi menjadi penghambat dalam efektivitas pemanfaatan dana desa. Untuk itu, Penulis berupaya untuk menganalisa permasalahan yang ada dan mencoba untuk mencari solusinya dengan melakukan metode penelitian yuridis normatif berdasarkan regulasi, data-data, teori-teori, dan kajian yang telah dilakukan sebelumnya dalam pelaksanaan dana desa. Hasilnya, opsi-opsi seperti menyalurkan dana desa langsung dari Rekening Kas Umum Negara (RKUN) ke Rekening Kas Desa (RKD) tanpa melalui Rekening Kas Umum Daerah (RKUD) dan memberlakukan mekanisme penyaluran dua tahap bagi desa mandiri kepada seluruh desa perlu untuk dicoba dalam mengatasi permasalahan teknis yang ada.
\end{abstract}

\begin{abstract}
The issuance of the Law no. 8 year 2014 on Village had grown an optimism in accelerating village development in Indonesia. However, technical issues such as the late disbursement from the local government, disbursement phases that limit the flexibility in managing the funds, and village governments' human resource limitations to fulfill the administrative tasks have hampered the effectivity of village funds utilization. Therefore, the Authors try to analyze the existing issues and explore the solutions by using normative legal research method based on regulation, data, theories, and research on the implementation of village funds. As the results, the options such as direct disbursement from the central government to village account and applying two-phase disbursement mechanism of independent villages to all villages should be considered to overcome the aforementioned technical issues.
\end{abstract}




\section{Pendahuluan}

Pasca reformasi yang terjadi pada tahun 1998 di Indonesia, terdapat banyak pergeseran kebijakan politik dan ekonomi yang sistematik dan mendasar terutama dengan munculnya porsi lebih besar kewenangan daerah dengan adanya otonomi daerah. Setelah selama 30 tahun berada pada rezim yang sentralistik, porsi pemerintah pusat menjadi dibatasi hanya pada sektor-sektor tertentu saja (Vel \& Bedner, 2015). Pergeseran peran tersebut ditandai dengan adanya perubahan aturan dana perimbangan keuangan antara pusat dan daerah berdasarkan Undang-Undang Nomor 25 Tahun 1999 tentang Perimbangan Keuangan antara Pemerintah Pusat dan Daerah.

Selain adanya otonomi dalam pemerintahan daerah, terdapat juga satu sistem pemerintahan yang lebih kecil yang disebut desa. Desa adalah kesatuan masyarakat hukum yang memiliki batas wilayah yang berwenang untuk mengatur dan mengurus urusan pemerintahan, kepentingan masyarakat setempat berdasarkan prakarsa masyarakat, hak asal usul, dan/atau hak tradisional yang diakui dan dihormati dalam sistem pemerintahan Negara Kesatuan Republik Indonesia (Republik Indonesia, 2014). Menurut Rifhi Siddiq (2006), desa merupakan suatu daerah yang memiliki tingkat kepadatan penduduk yang rendah dengan interaksi sosial bersifat homogen dan mayoritas penduduknya bermata pencaharian petani karena umumnya di pedesaan berupa wilayah agraris.

Jumlah desa yang ada saat ini sangat banyak dan tersebar di seluruh wilayah Indonesia. Berdasarkan data Badan Pusat Statistik, pada tahun 2018, jumlah desa yang ada di Indonesia sebanyak 83.901 desa (Badan Pusat Statistik, n.d.). Desa memiliki potensi untuk dapat menjadi motor pergerakan ekonomi baru di dalam menumbuhkan geliat perekonomian masyarakat. Pasca dibentuknya Undang-Undang Nomor 6 Tahun 2014 tentang Desa (UU Desa), maka secara legal formal negara mengakui peran desa untuk dapat berpartisipasi lebih jauh untuk mengelola wilayah dan masyarakat di dalamnya. Upaya pemerintah dalam memaksimalkan peran desa ini juga dinyatakan dengan adanya dana desa yang diberikan setiap tahun untuk digunakan dalam hal pembangunan dan pemberdayaan masyarakat desa. Terdapat banyak optimisme dengan disahkannya UU Desa. Meskipun begitu, pembentukan aturan hukum sebagai strategi untuk mencapai perubahan sosial politik tidak berakhir hanya dengan pengesahan Undang-Undang (J. Vel et al., 2017). Diperlukan komitmen dan langkah-langkah lanjutan guna mewujudkan tujuan dari Undang-Undang yang dihasilkan.

Beberapa permasalahan kerap terjadi dari tahun ke tahun dalam penyaluran dana desa, seperti dugaan tidak transparan, mark up, penggunaan fiktif dana desa, proyek tidak sesuai kebutuhan, dan tidak sesuai aturan dalam pengelolaan dana desa oleh oknum aparat desa. (Isti, 2019) Selain itu, penyaluran dana desa yang terdiri dari beberapa tahap serta birokrasi persyaratan dana desa yang rumit juga menjadi momok utama dalam penggunaan dana desa bagi pemberdayaan masyarakat berkelanjutan (KOMPAK \& Bappenas, 2019). Terdapat beberapa penelitian serupa terkait dana desa, diantaranya "Keterlambatan Implementasi penyaluran Dana Desa" (Ardhi, 2018) yang berfokus pada pelaksanaan dana desa di Kabupaten Pacitan dan penelitian terkait implementasi penyaluran dana desa di Kabupaten Sambas, Kalimantan Barat (Muliawan et al., 2019). Kedua penelitian tersebut secara garis besar menghasilkan kesimpulan yang serupa, yakni masih terdapatnya permasalahan-permasalahan teknis yang menyebabkan keterlambatan dana desa. Ardhi menyoroti pada terlambatnya penerbitan peraturan daerah dan juga mengkritisi jadwal penyaluran dana desa yang mengakibatkan menumpuknya beban kerja perangkat desa. Sementara itu, Muliawan lebih menekankan pada pentingnya peningkatan koordinasi antar lembaga pemerintahan baik pusat maupun daerah.

Berbeda dengan kedua penelitian tersebut yang berfokus pada satu daerah tertentu, penelitian ini lebih mencoba melihat kebijakan penyaluran dana desa melalui perspektif makro di tingkat nasional dengan melihat data-data yang ada serta kajian serupa yang telah dilakukan di berbagai daerah sebelumnya. 
Selain itu, penelitian ini juga mencoba melakukan studi kasus dengan membandingkan mekanisme penyaluran dana desa dengan mekanisme penyaluran dana dari pemerintah pusat lainnya seperti dana Bantuan Operasional Sekolah (BOS). Hingga saat ini, belum ada penelitian sejenis yang secara khusus menggunakan pendekatan ini pada topik penyaluran dana desa.

\section{Metode}

Penelitian ini dilakukan dengan menggunakan metode penelitian yuridis normatif dimana analisis yang dilakukan didasarkan pada peraturan perundang-undangan yang berlaku dan relevan dengan isu yang ingin difokuskan pada tulisan ini. Penelitian yuridis normatif merupakan penelitian yang meletakkan hukum sebagai sebuah bangunan sistem norma, yang terdiri dari asas-asas, norma, kaidah dari peraturan perundangan, putusan pengadilan, perjanjian serta doktrin (Fajar \& Achmad, 2013). Dalam penelitian yuridis normatif, penelitian hukum dilakukan dengan cara meneliti bahan pustaka atau data sekunder (Soekanto \& Mahmudji, 2015).

Penulis mencoba untuk mengkaji lebih jauh terkait regulasi yang mengatur dana desa dan permasalahan-permasalahan yang terjadi di lapangan pada implementasi dana desa. Regulasi yang dikaji mulai dari Undang-Undang, Peraturan Pemerintah, hingga Peraturan Menteri yang terkait mengenai kebijakan dana desa. Penulis juga melakukan studi kasus terhadap aturan-aturan terkait pemberian dana Bantuan Operasional Sekolah (BOS) yang telah diimplementasikan, untuk kemudian diuji kemungkinan diadaptasinya mekanisme tersebut dalam aturan dan pelaksanaan penyaluran dana desa. Dana BOS dipilih sebagai perbandingan dikarenakan dana BOS juga merupakan anggaran yang ditransfer dari Rekening Kas Umum Negara (RKUN).

Data utama yang dipergunakan pada penelitian ini adalah peraturan perundangundangan terkait dana desa. Selain itu, data-data lain yang digunakan untuk menunjang data utama tersebut berasal dari buku, jurnal, dan laporan penelitian yang berkaitan dengan permasalahan yang diteliti. Dalam menganalisis data-data tersebut, Penulis melakukan analisis data kualitatif dan studi kasus guna mengeksplorasi opsi-opsi kebijakan yang dapat ditempuh. Hal tersebut untuk memberikan inovasi baru yang muncul agar dapat memberikan solusi khususnya dalam tataran aturan yuridis yang saat ini berlaku.

\section{Hasil Dan Pembahasan}

\section{III.1.Kebijakan Dana Desa di Indonesia}

Keberadaan desa telah ada sebelum Negara Kesatuan Republik Indonesia terbentuk. Penjelasan Pasal 18 Undang-Undang Dasar Negara Republik Indonesia Tahun 1945 (sebelum perubahan) menyebutkan bahwa "Dalam teritori Negara Indonesia terdapat lebih kurang 250 "Zelfbesturende landschappen" dan "Volksgemeenschappen", seperti desa di Jawa dan Bali, nagari di Minangkabau, dusun dan marga di Palembang, dan sebagainya. Daerah-daerah itu mempunyai susunan asli dan oleh karenanya dapat dianggap sebagai daerah yang bersifat istimewa. Negara Republik Indonesia menghormati kedudukan daerah-daerah istimewa tersebut dan segala peraturan negara yang mengenai daerah-daerah itu akan mengingati hak-hak asal usul daerah tersebut. Oleh sebab itu, keberadaannya wajib tetap diakui dan diberikan jaminan keberlangsungan hidupnya dalam Negara Kesatuan Republik Indonesia (Republik Indonesia, 2014).

Dibentuknya UU Desa merupakan bentuk komitmen pemerintah di dalam mengakui keberadaan desa. Prinsip-prinsip utama yang mendasari UU Desa antara lain: (i) Desa memiliki hak untuk mengatur dan mengelola kepentingan masyarakatnya sendiri; (ii) Desa perlu menjadi mandiri dan demokratis untuk menuju masyarakat yang maju; dan (iii) Desa dikelola melalui peraturan di tingkat desa (Salim et al., 2017). Perubahan-perubahan utama yang diakomodir pada UU Desa diantaranya mekanisme akuntabilitas kepala desa melalui musyawarah desa, kewenangan yang lebih besar pada Badan Permusyawaratan Desa (BPD), peningkatan transparansi, kolaborasi 
antar desa, dan peningkatan pendanaan kepada desa yang substansial (Antlöv et al., 2016). Peningkatan pendanaan kepada desa dari pemerintah pusat yang diberikan dalam wujud dana desa merupakan bentuk komitmen negara dalam hal peningkatan kapasitas desa, yang diharapkan dapat meningkatkan kesejahteraan masyarakat desa.

Dana desa adalah dana yang bersumber dari Anggaran Pendapatan dan Belanja Negara (APBN) yang diperuntukkan bagi desa yang ditransfer melalui anggaran pendapatan dan belanja daerah kabupaten/kota dan digunakan untuk membiayai penyelenggaraan pemerintahan, pelaksanaan pembangunan, pembinaan kemasyarakatan, dan pemberdayaan masyarakat (Republik Indonesia, 2016). Sebagaimana diatur pada Pasal 72 UU Desa, dana desa merupakan salah satu sumber pendapatan yang dimiliki oleh desa. Pemberian dana desa telah dimulai sejak tahun 2015 dimana jumlah dana yang disalurkan sebesar Rp 20,76 triliun (Simorangkir, 2017). Jumlah tersebut terus meningkat setiap tahun, dan bila dihitung sampai 2019, setidaknya uang yang telah digelontorkan pemerintah untuk dana desa sebesar Rp 275 triliun (Pertana, 2019).

Dalam pelaksanaannya, dana desa telah berhasil menurunkan jumlah penduduk miskin di pedesaan dari 17,89 juta (14,09\%) pada tahun 2015 menjadi 14,93 juta (12,6\%) pada tahun 2019 (Direktorat Jenderal Perimbangan Keuangan, 2021). Dalam hal pembangunan, pemanfaatan dana desa selama periode 2015-2017 mampu menghasilkan sarana dan prasarana yang bermanfaat bagi masyarakat. Hal ini terbukti selama kurun waktu tersebut, pengucuran dana desa telah berhasil membangun $199.100 \mathrm{~km}$ jalan desa, $1.599 \mathrm{~km}$ jembatan, 325.599 unit sambungan air bersih, 4.656 unit embung desa, 48.271 unit Posyandu, 19.794 unit pasar desa, 43.723 unit PAUD desa, 342.137 unit sumur dan MCK, serta 299.345 unit drainase dan irigasi (Setiawan, 2018).

Dalam melaksanakan kegiatan dengan penggunaan dana desa, desa tidak bisa serta merta untuk membuat rencana kegiatan. Terdapat target prioritas kegiatan yang dapat dilakukan oleh desa yang diatur setiap tahun, sebagaimana diatur pada Permendesa PDTT Nomor 13 Tahun 2020 tentang Prioritas Penggunaan Dana Desa Tahun 2021 (Kementerian Desa Pembangunan Daerah Tertinggal dan Transmigrasi, 2020). Dalam hal penyaluran dana desa, berdasarkan Permendagri Nomor 20 Tahun 2018 tentang Pengelolaan Keuangan Desa (Kementerian Dalam Negeri, 2018), diperlukan pembentukan peraturan bupati/wali kota tentang penyusunan Anggaran Pendapatan dan Belanja Desa (APBDes), yang merupakan sinkronisasi kebijakan pemerintah daerah kabupaten/kota dengan kewenangan desa, Rencana Kerja Pemerintah (RKP) desa, dan kebijakan prioritas penggunaan dana desa.

Terkait sisa dana desa, terdapat konsekuensi bila dana desa tersebut tidak terserap. Ketentuan Pasal 27 Peraturan Pemerintah Nomor 8 Tahun 2016 Tentang Dana Desa yang bersumber dari APBN menjelaskan bahwa desa dapat dijatuhi sanksi apabila terdapat lebih dari 30\% (tiga puluh persen) dana desa yang tersisa pada akhir tahun anggaran.

\section{III.2. Permasalahan Pada Implementasi Penyaluran Dana Desa III.2.1.Beban Administratif dan Sulitnya Tahapan Penyaluran}

Sebagaimana tercantum pada Pasal 23 ayat (4) Peraturan Menteri Keuangan Nomor 222/PMK.07/2020 tentang Pengelolaan Dana Desa (Kementerian Keuangan, 2020a), secara umum proses penyaluran dana desa dilakukan dalam tiga tahap. Tahap pertama sebesar 40\%, tahap kedua sebesar 40\%, dan tahap ketiga sebesar 20\% dari pagu anggaran.

Dengan adanya tiga tahap penyaluran dana desa tersebut, ini artinya pemerintah desa harus membuat tiga kali pelaporan terhadap realisasi penggunaan dana desa dan juga persyaratan dokumen lainnya sebagaimana diatur pada Pasal 24 Peraturan Menteri Keuangan Nomor 222/PMK.07/2020 tentang Pengelolaan Dana Desa.

Banyaknya beban administratif yang harus dipenuhi pada kenyataannya membuat perangkat desa kewalahan. Akibatnya, ada desa yang terpaksa memakai jasa percaloan pembuatan APBDes dan membuat dokumen fiktif guna memenuhi seluruh persyaratan 
tersebut. Urgensi persyaratan dokumen yang terlalu banyak juga perlu dikaji ulang karena pada beberapa kasus ditemukan bahwa persyaratan yang diperlukan tersebut bisa sia-sia karena ada pemerintah daerah yang tidak mengutamakan kualitas dokumen dan menganggapnya sekadar formalitas (Sedyadi \& Isdijosi, 2017).

Berdasarkan hasil penelitian Reality Check Approach pada tahun 2015, ditemukan bahwa beban kerja kepala desa jauh meningkat secara administratif. Hal ini menyebabkan kurangnya waktu yang dimiliki oleh kepala desa untuk melayani kepentingan warganya (KOMPAK, 2016). Hal ini dapat dimaklumi melihat banyaknya pekerjaan administratif yang harus dilakukan seorang kepala desa dalam mengelola dana desa. UU Desa telah banyak merubah peran dan tanggung jawab dari seorang kepala desa. Jika sebelumnya sosok kepala desa lebih banyak hadir di tengah masyarakat, setelah terbitnya Undang-Undang tersebut kepala desa mendapatkan banyak tugas administratif tambahan mulai dari perencanaan hingga pelaporan realisasi dari dana desa. Hal ini menambah tugas administrasi kepala desa yang telah ada sebelumnya seperti membuat APBDes dan Rencana Pembangunan Jangka Menengah Desa (RPJMDes) yang telah ada semenjak masa reformasi. Akan tetapi, jika dahulu penyusunan APBDes seakan hanya berbasis angan-angan, semenjak diundangkannya Undang-Undang Desa penyusunan APBDes sudah dapat dilakukan berdasarkan anggaran yang nyata akan mereka dapatkan (Cahyono et al., 2020).

Dengan bertambahnya beban administratif perangkat desa secara signifikan, sayangnya hal tersebut tidak sejalan dengan peningkatan kualitas maupun kuantitas dari perangkat desa. Meskipun perangkat desa bukan merupakan pegawai negeri sipil, mayoritas kepala desa yang terpilih mempertahankan perangkat desa dari kepemimpinan yang sebelumnya (Salim et al., 2017).

Fokus pemerintah pada penyerapan anggaran yang kemudian diejawantahkan melalui tiga tahap penyaluran dana desa dapat menyulitkan desa dalam membiayai kegiatan-kegiatan besar maupun pembangunan infrastruktur yang membutuhkan biaya besar. Tahap penyaluran tahap pertama sebesar $40 \%$ dirasa tidak mencukupi untuk menganggarkan hal-hal tersebut. Salah satu akibatnya, kebanyakan desa menggunakan dana desa untuk proyek infrastruktur berskala kecil (The World Bank, 2020). Penyaluran ketiga yang dapat diterima hingga bulan Desember juga menyulitkan desa untuk menggunakannya secara efektif (KOMPAK \& Bappenas, 2019).

Semangat awal UU Desa salah satunya adalah untuk mengakui otonomi pada tingkat desa (Asian Development Bank, 2016). Akan tetapi, pada pengaturannya justru terlihat ambigu. Pengakuan otonomi selayaknya dilakukan dengan unconditional cash transfer program (Utami, 2017), dimana dana yang diberikan dapat dipergunakan desa tanpa adanya ketentuan tentang bagaimana dana tersebut harus digunakan. UU Desa hingga peraturan turunannya justru memberikan ketentuan-ketentuan mengikat terkait prioritas penggunaan dana desa yang seakan-akan mengaburkan makna "otonomi" itu sendiri.

\section{III.2.2. Perlakuan Berbeda bagi Desa Mandiri}

Penyaluran dana desa yang terdiri atas tiga tahapan tidak berlaku bagi seluruh desa. Pasal 23 Peraturan Menteri Keuangan Nomor 222/PMK.07/2020 tentang Pengelolaan Dana Desa membedakan tahapan penyaluran antara desa yang berstatus desa mandiri dengan desa-desa lainnya. Lebih lanjut, pasal tersebut mendefinisikan desa mandiri sebagai status desa hasil penilaian yang dilakukan setiap tahun dan ditetapkan oleh Kementerian Desa, Pembangunan Daerah Tertinggal, dan Transmigrasi dalam Indeks Desa. Perbedaan secara mendetail antara kedua jenis desa tersebut pada Pada tabel 1 tergambar perbedaan mendetail antara desa mandiri dan desa lainnya (dalam tulisan ini Penulis sebut sebagai desa reguler) terkait tahapan-tahapan pencairan dana desa. 
Tabel 1. Perbandingan antara Desa Reguler dengan Desa Mandiri

\begin{tabular}{|c|c|c|}
\hline & Desa Reguler & Desa Mandiri \\
\hline $\begin{array}{l}\text { Alokasi dan waktu } \\
\text { penyaluran Dana Desa }\end{array}$ & $\begin{array}{l}\text { Tahap I: Paling cepat Januari, } 40 \% \\
\text { pagu }\end{array}$ & $\begin{array}{l}\text { Tahap I: Paling cepat Januari, } 60 \% \\
\text { pagu }\end{array}$ \\
\hline $\begin{array}{l}\text { Alokasi dan waktu } \\
\text { penyaluran Dana Desa }\end{array}$ & $\begin{array}{l}\text { Tahap II: Paling cepat Maret, } 40 \% \text { pagu } \\
\text { Tahap III: Paling cepat Juni, 20\% pagu }\end{array}$ & $\begin{array}{l}\text { Tahap II: Paling cepat Maret, } 40 \% \\
\text { pagu }\end{array}$ \\
\hline $\begin{array}{l}\text { Persyaratan } \\
\text { penyaluran Dana Desa }\end{array}$ & $\begin{array}{l}\text { Tahap I: } \\
\text { 1. Peraturan bupati/wali kota } \\
\text { mengenai penetapan rincian dana } \\
\text { desa setiap desa } \\
\text { 2. Peraturan desa mengenai APBDes } \\
\text { 3. Surat Kuasa Pemindahbukuan dari } \\
\text { kepala daerah } \\
\text { Tahap II: } \\
\text { 1. Laporan realisasi penyerapan \& } \\
\text { capaian keluaran dari dana desa } \\
\text { tahun anggaran sebelumnya } \\
\text { 2. Laporan realisasi penyerapan } \\
\text { tahap I min.50\% \& capaian } \\
\text { keluaran min.35\% } \\
\text { 3. Peraturan kepala desa mengenai } \\
\text { KPM BLT desa atau peraturan } \\
\text { kepala desa mengenai tidak } \\
\text { terdapat KPM } \\
\text { 4. Berita acara konfirmasi dan } \\
\text { rekonsiliasi kumulatif sisa dana } \\
\text { desa TA } 2015 \text { s.d. } 2019 \\
\text { Tahap III: } \\
\text { 1. Laporan realisasi penyerapan s.d, } \\
\text { tahap II min. } 90 \% \text { \& capaian } \\
\text { keluaran min. } 75 \% \\
\text { 2. Laporan konvergensi pencegahan } \\
\text { stunting }\end{array}$ & $\begin{array}{l}\text { Tahap I: } \\
\text { 1. Peraturan bupati/wali kota } \\
\text { mengenai penetapan rincian dana } \\
\text { desa setiap desa } \\
\text { 2. Peraturan desa mengenai APBDes } \\
\text { 3. Surat Kuasa Pemindahbukuan dari } \\
\text { kepala daerah } \\
\text { Tahap II: } \\
\text { 1. Laporan realisasi penyerapan \& } \\
\text { capaian keluaran dari dana desa } \\
\text { tahun anggaran sebelumnya } \\
\text { 2. Laporan realisasi penyerapan } \\
\text { tahap I min.50\% \& capaian } \\
\text { keluaran min.35\% } \\
\text { 3. Peraturan kepala desa mengenai } \\
\text { KPM BLT desa atau peraturan } \\
\text { kepala desa mengenai tidak } \\
\text { terdapat KPM } \\
\text { 4. Laporan konvergensi pencegahan } \\
\text { stunting } \\
\text { 5. Berita acara konfirmasi dan } \\
\text { rekonsiliasi kumulatif sisa dana } \\
\text { TA } 2015 \text { s.d. } 2019\end{array}$ \\
\hline
\end{tabular}

Sumber: PMK 222/PMK.07/2020 tentang Pengelolaan Dana Desa

Dari tabel 1 tersebut, dapat dipahami bahwa pemerintah berupaya untuk menjadikan kemudahan-kemudahan dalam penyaluran dana desa sebagai insentif yang dapat mendorong desa-desa untuk terus berupaya mencapai status desa mandiri. Akan tetapi, pilihan kebijakan tersebut perlu dicermati lebih jauh. Membebani desa yang belum berstatus sebagai desa mandiri dengan beban administratif yang lebih besar dan tahapan penyaluran yang lebih mengikat bisa jadi kontraproduktif mengingat kebijakan ini justru mempersulit desa-desa yang secara kapasitas masih tertinggal.

Berdasarkan data dari Kementerian Keuangan, Indonesia memiliki 831 desa mandiri, 8.634 desa maju, 38.463 desa berkembang, 20.370 desa tertinggal, dan 6.653 desa sangat tertinggal (Direktorat Jenderal Perimbangan Keuangan, 2021). Akan sangat memakan banyak sumber daya baik dari tenaga, waktu, maupun fiskal untuk dapat terus menerus mengawasi penyerapan dana desa. Mekanisme baru yang lebih efektif dan efisien perlu untuk dirumuskan.

\section{III.2.3. Belajar dari Perubahan Skema Transfer Bantuan Operasional Sekolah (BOS)}

Berdasarkan Pasal 23 Peraturan Menteri Keuangan Nomor 222/PMK.07/2020, dana desa disalurkan dari Rekening Kas Umum Negara (RKUN) ke Rekening Kas Desa (RKD) melalui Rekening Kas Umum Daerah (RKUD). Penyaluran yang harus melalui RKUD menimbulkan beberapa masalah seperti keterlambatan dana desa sampai ke RKD karena permasalahan administratif yang terjadi saat pemindahbukuan dari RKUD ke RKD. Salah satunya adalah belum diterbitkannya peraturan pelaksanaan dana desa oleh Pemerintah Daerah, walaupun dana sudah diterima di RKUD (Ardhi, 2018). Merujuk pada Pasal 24 Peraturan Menteri Keuangan Nomor 222/PMK.07/2020, pemerintah 
daerah perlu menetapkan Peraturan Bupati/Walikota mengenai tata cara pembagian dan penetapan rincian dana desa setiap desa. Proses penetapan Peraturan Bupati/ Walikota yang berlarut kerap menjadi permasalahan utama yang mengakibatkan tidak tepat waktunya penyaluran dana desa.

Untuk dapat mengatasi permasalahan-permasalah tersebut, dapat kita bandingkan dengan penyaluran dana Bantuan Operasional Sekolah (BOS). Seperti halnya penyaluran dana desa, sebelumnya BOS disalurkan dari RKUN ke RKUD untuk kemudian disalurkan ke rekening sekolah. Ketika itu, banyak terjadi permasalahan yang menyebabkan sekolah sering terlambat menerima penyaluran dana BOS (hingga Maret/April), banyak kepala sekolah terpaksa menalangi biaya operasional sekolah awal tahun, hingga keterlambatan dana BOS yang mengganggu proses pembelajaran siswa (Kementerian Pendidikan dan Kebudayaan, 2020).

Pemerintah pusat melalui Menteri Keuangan, Menteri Pendidikan dan Kebudayaan, serta Menteri Dalam Negeri memutuskan untuk merevitalisasi mekanisme penyaluran dana BOS. Mulai tahun 2020, dana BOS tidak lagi disalurkan dari RKUN melalui RKUD. Pada mekanisme baru ini, dana BOS akan langsung dicairkan dari RKUN ke rekening sekolah (Kementerian Keuangan, 2020c). Kebijakan ini direalisasikan dengan dikeluarkannya Peraturan Menteri Keuangan (PMK) Nomor 9 Tahun 2020 tentang perubahan atas PMK Nomor 48 tahun 2019 tentang pengelolaan DAK Non Fisik (Kementerian Keuangan, 2020b). Pasal 19 ayat (3) pada PMK tersebut menyatakan bahwa penyaluran dana BOS dilaksanakan dengan cara pemindahbukuan dari RKUN ke rekening sekolah.

Mekanisme ini dapat dicoba untuk diaplikasikan dalam penyaluran dana desa. Seperti halnya permasalahan yang terdapat pada penyaluran dana BOS sebelumnya, penyaluran melalui RKUD kerap kali menambah panjang proses administrasi. Penyaluran yang tepat waktu merupakan salah satu faktor yang sangat esensial guna mengoptimalkan pemanfaatan dana desa oleh desa. Sebagai sebuah entitas yang baru memiliki otonomi besar, desa memerlukan waktu untuk dapat menggunakan dana desa seefektif dan seefisien mungkin. Keterlambatan penyaluran mengakibatkan desa memiliki waktu yang lebih sempit lagi dalam mengimplementasikan penggunaan dana desa.

\section{III.3. Keterbatasan Kapasitas Sumber Daya Manusia}

Hingga tahun 2018, masih sangat banyak perangkat desa yang berpendidikan rendah. 1.017 kepala desa tidak pernah bersekolah, 907 kepala desa tidak menyelesaikan sekolah dasar, 1.656 kepala desa dengan pendidikan terakhir sekolah dasar/sederajat, dan 7.545 kepala desa dengan pendidikan terakhir sekolah menengah pertama/ sederajat. Selain itu, juga terdapat 327 sekretaris desa tidak pernah bersekolah, 461 sekretaris desa tidak menyelesaikan sekolah dasar, 1.302 sekretaris desa dengan pendidikan terakhir sekolah dasar/sederajat, dan 3.615 sekretaris desa dengan pendidikan terakhir sekolah menengah pertama/sederajat (Harmadi et al., 2020). Salah satu penyebab utamanya ditengarai akibat warga desa dengan pendidikan yang lebih tinggi tidak ingin bekerja di pemerintah desa (Khairullah, 2018). Di atas kertas, sulit untuk mengharapkan perangkat desa dapat mengerjakan tanggung jawab administratif yang melekat pada mereka dalam implementasi dana desa. Pembimbingan dan upaya peningkatan kapasitas yang berkesinambungan menjadi amat penting untuk dilakukan. Rendahnya kapasitas kepala desa dalam beberapa kasus terbukti mengakibatkan mekanisme Musrenbang tidak dilalui sesuai prosedur (Kartika, 2018).

Dalam kurun waktu 2015-2019 sebanyak 473 kepala desa seluruh Indonesia tersandung masalah hukum akibat penyalahgunaan dana desa (Antara, 2020). Jumlah ini dapat terus bertambah apabila pembinaan terhadap aparat desa mengenai penggunaan dana desa tidak berjalan dengan baik. Ketidakjelasan terhadap regulasi dan mekanisme juga menyebabkan masyarakat memiliki kesulitan dalam mengawasi proses pembangunan yang mengakibatkan rendahnya pengawasan masyarakat terhadap kepala desa (Herdiana, 2019). 
Dalam pelaksanaan dana desa, kejelasan aturan dan tumpang tindih aturan menjadi problem yang cukup pelik mengingat banyak pihak yang terlibat didalamnya. Kepala desa yang umumnya tidak memiliki kemampuan teknis mengenai anggaran negara tentu menjadi celah terjadinya penyelewengan dana desa baik yang disengaja ataupun tidak disengaja. Jumlah dana desa yang sangat besar dan memerlukan laporan yang kompleks dari perencanaan hingga laporan evaluasi menjadi tugas berat pemerintah desa dalam hal meminimalisir terjadinya kesalahan penggunaan dana desa. Untuk itu, intensitas sosialisasi UU Desa dan peraturan pelaksanaannya perlu ditingkatkan, disertai dengan kegiatan saling berbagi pengetahuan dan pengalaman baik antar aparat desa dengan supra desa (Aminah \& Sutanto, 2018).

Regulasi yang ada dalam pengaturan dana desa juga menjadi masalah tambahan bagi aparat desa, dimana banyak instansi yang terlibat dalam pelaksanaan dana desa. Hal ini berpotensi menimbulkan tumpang tindih kewenangan antar lembaga (Adji et al., 2019). Dalam tataran tingkat pusat, setidaknya ada Kementerian Keuangan, Kementerian Dalam Negeri, Kementerian Desa, Pembangunan Daerah Tertinggal, dan Transmigrasi, serta BPKP. Dalam tataran tingkat daerah pun juga melibatkan pemerintah daerah provinsi dan kabupaten. Pengaturan terkait dana desa pun cukup banyak dan beragam dari Undang-Undang, Peraturan Pemerintah, Peraturan Menteri, hingga Peraturan Bupati/Walikota. Banyaknya pihak dan beragamnya aturan ini tentu sangat menyulitkan bagi aparat desa yang tidak semua memiliki kapasitas yang seragam. Hal ini tentu berpotensi menimbulkan masalah, dimana persoalan dana desa menjadi lebih banyak berfokus pada urusan administrasi dibandingkan pelaksanaan.

Pemerintah perlu melakukan pengawasan kinerja kepala desa melalui kementerian terkait dalam bentuk monitoring dan evaluasi terhadap hasil kerja pemerintah desa yang meliputi pengawasan terhadap perencanaan kegiatan pemerintah desa, pelaksanaan kegiatan, dan laporan penyelenggaraan pemerintahan desa akan menjadi sarana kontrol agar aparat desa tidak salah dalam pelaksanaan kebijakan penggunaan dana desa (Enggraini et al., 2020).

\section{III.4. Dana Desa untuk Pemberdayaan Masyarakat dan Pembangunan Berkelanjutan}

Semangat awal UU Desa yang ingin memberikan otonomi pada desa tercermin pada bagian menimbang yang secara tegas menyebutkan "bahwa desa memiliki hak asal usul dan hak tradisional dalam mengatur dan mengurus kepentingan masyarakat setempat dan berperan mewujudkan cita-cita kemerdekaan berdasarkan UndangUndang Dasar Negara Republik Indonesia Tahun 1945." Menurut Soejamto (Soejamto, 1988), hak asal-usul mencakup tiga elemen, yaitu: 1) struktur kelembagaan; 2) mengatur dan mengurus urusan-urusan pemerintahan, terutama yang berhubungan dengan pelayanan publik dan pembebanan; dan 3) menentukan sendiri cara untuk memilih dan memberhentikan pimpinannya.

Pemberian dana desa dapat menjadi sarana yang efektif dalam mendorong pemberdayaan masyarakat. Ketika desa memiliki otonomi, meskipun mereka harus melalui literasi yang terus-menerus, desa diberikan self-determination untuk dapat menyusun prioritas mereka sendiri (Utami, 2017). Dengan begitu, desa-desa tersebut akan menjadi berdaya dalam proses pengambilan keputusan mereka. Adanya dana desa secara tidak langsung mewujudkan demokrasi di kalangan bawah, melalui peningkatan partisipasi masyarakat dalam menentukan penggunaan dana desa. Sayangnya, suara perempuan belum begitu diperhatikan (Sofianto, 2017). Proses pemberdayaan masyarakat desa juga penting untuk memastikan kesetaraan gender (Kristianti, 2020). Perempuan di desa perlu untuk memahami bahwa mereka memiliki hak dan posisi yang sama dengan laki-laki dalam pengambilan keputusan di tingkat desa (Kushandajani \& Alfirdaus, 2019).

UU Desa telah memberikan kewenangan yang lebih pada desa untuk dapat mengambil keputusan di tingkat desa melalui pengaturan terkait musyawarah desa yang merupakan forum permusyawaratan yang diikuti oleh Badan Permusyawaratan Desa, pemerintah desa, dan unsur masyarakat desa untuk memusyawarahkan hal yang 
bersifat strategis dalam penyelenggaraan pemerintahan desa (Republik Indonesia, 2014). Meningkatnya legitimasi perangkat desa pada UU Desa dan ditambah dengan adanya dana desa yang perlu dikelola, hal tersebut telah mendorong masyarakat desa untuk lebih serius dalam berpartisipasi pada musyawarah desa (Utami, 2017).

Akan tetapi, pendekatan top-down seakan masih sangat sulit untuk dapat ditinggalkan. Meskipun masyarakat desa memiliki kesempatan untuk lebih berdaya melalui musyawarah desa yang kini memiliki legitimasi yang kuat, pemerintah pusat tetap memberikan batasan-batasan dan prioritas yang harus diikuti oleh desa sebagaimana diatur pada Peraturan Menteri Keuangan Nomor 222/PMK.07/2020 tentang Pengelolaan Dana Desa dan Peraturan Menteri Desa, Pembangunan Daerah Tertinggal, dan Transmigrasi Nomor 13 Tahun 2020 tentang Prioritas Penggunaan Dana Desa Tahun 2021. Jika memang tujuannya adalah untuk melakukan pemberdayaan, pemerintah desa juga perlu diberi kepercayaan untuk merumuskan prioritas mereka sendiri. Bagaimanapun, Indonesia merupakan negara yang sangat besar dengan kondisi alam dan budaya yang sangat beragam. Sulit untuk dapat memaksa seluruh desa yang ada memiliki prioritas yang serupa. Pendekatan-pendekatan yang lebih inklusif perlu untuk dicoba dilakukan, dimana aparat desa juga dapat menentukan prioritas mereka sendiri tanpa terlalu terikat kewajiban untuk mengikuti prioritas yang ditetapkan oleh pemerintah pusat. Diaturnya prioritas penggunaan dana desa dalam dua aturan hukum yang berbeda juga menambah kesulitan desa dalam menentukan prioritasnya.

Hingga kini penggunaan dana desa masih belum dapat dioptimalkan penggunaannya untuk dapat mewujudkan tujuan pembangunan berkelanjutan seperti program pencegahan stunting, penyediaan air bersih, pencegahan perubahan iklim, dan lain sebagainya. Berdasarkan data yang dikeluarkan oleh Bank Dunia, porsi terbesar penggunaan dana desa masih pada keperluan pemerintahan seperti gaji perangkat desa, dana operasional untuk RT/RW/KADIS/BKD, infrastruktur kantor desa, dan lainnya (The World Bank, 2019).

Tabel 2. Pengeluaran Desa berdasarkan Klasifikasi Urusan.

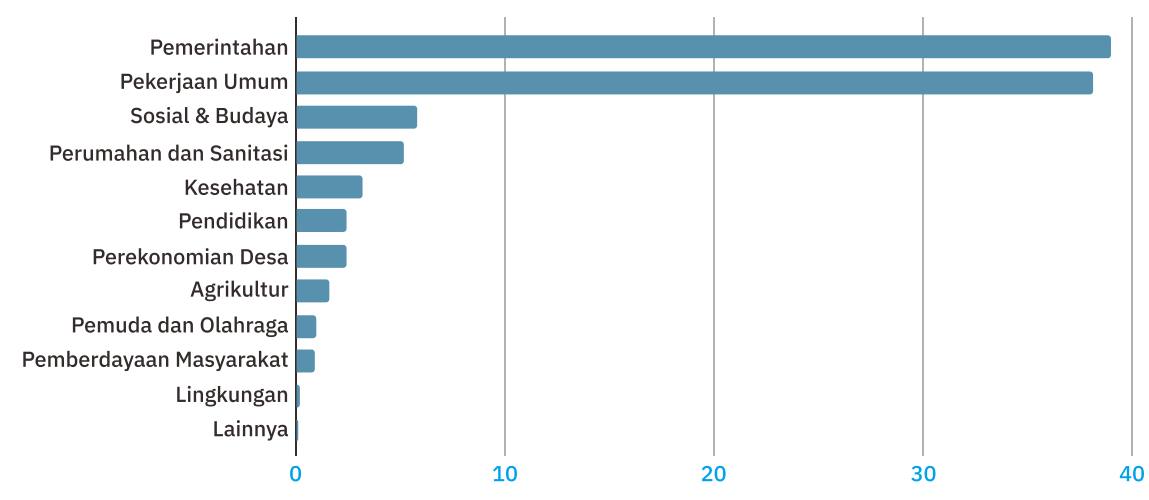

Sumber: World Bank Village Public Expenditure Review (VIPER) 2017

Fleksibilitas dalam tiap tahapan penganggaran juga perlu ditingkatkan untuk memberi desa keleluasaan dalam memanfaatkan dana desa dengan lebih bermakna. Berdasarkan studi yang dilakukan oleh tim peneliti Reality Check Approach (KOMPAK, 2016), mayoritas kepala desa pada lokasi tempat penelitian dilaksanakan mengutamakan pembangunan jalan dikarenakan hal tersebut merupakan opsi termudah dalam menggunakan dana desa. Apalagi ketika dana diterima mendekati akhir tahun anggaran dan perlu untuk segera dimanfaatkan. Hal-hal yang bersifat fisik atau infrastruktur dirasa lebih mudah ketimbang program pemberdayaan masyarakat yang secara administratif tidak mudah terukur (Luthfi et al., 2017). Temuan ini semakin memperkuat data dari Kementerian Desa dan Pembangunan Daerah Tertinggal (Kementerian Desa Pembangunan Daerah Tertinggal dan Transmigrasi, n.d.) yang menunjukkan pembangunan jalan sebagai salah satu output terbesar dari dana desa, bahkan dalam kurun waktu 2015-2019 sudah 231.709 km jalan yang sudah dibangun dari dana desa. 
Selain itu, peran pendamping desa harus semakin diperkuat untuk meningkatkan pemberdayaan masyarakat desa. Perguruan tinggi dan lembaga swadaya masyarakat dapat berperan aktif dalam membantu desa merumuskan penggunaan dana desa yang optimal. Paradigma yang digunakan tidak seharusnya terlalu berfokus pada tertib administrasi (Syukri et al., 2018), dan perlu lebih berfokus pada meningkatkan pemberdayaan masyarakat maupun mewujudkan tujuan pembangunan berkelanjutan.

\section{Kesimpulan}

Berdasarkan analisis dan uraian di atas, didapat kesimpulan bahwa efektivitas implementasi dana desa untuk pembangunan desa masih sangat terhambat oleh kebijakan tiga tahap penyaluran dana desa yang membebani kepala desa dengan banyak beban administratif dan mempersulit desa dalam memaksimalkan penyerapan anggaran untuk hal-hal yang bermakna dalam mendorong pemberdayaan masyarakat maupun tujuan pembangunan berkelanjutan. Mekanisme-mekanisme yang ada pada saat ini dirasa belum dapat sepenuhnya mengejawantahkan semangat pemberian otonomi pada desa dari UU Desa sehingga perlu untuk disederhanakan. Selain itu, tumpang tindih kewenangan dan regulasi kerap membingungkan kepala desa dan aparatnya yang secara kapasitas SDM masih relatif lemah.

Ada beberapa saran yang dapat diberikan Penulis berdasarkan kesimpulan di atas. Pertama, perlunya koordinasi yang lebih jelas di tingkat instansi pemerintah terkait leading sector pengelolaan dana desa untuk mempermudah kepala desa dan aparat desa dalam menjalankan tanggungjawabnya. Dalam hal ini, Kementerian Desa, Pembangunan Daerah Tertinggal, dan Transmigrasi selaku pemangku kepentingan utama terkait desa perlu menjadi leading sector. Harapannya, permasalahan tumpang tindih seperti diaturnya prioritas penggunaan dana desa dalam dua produk hukum yang berbeda yakni Peraturan Menteri Keuangan dan Permendesa PDTT dapat teratasi. Seiring dengan hal tersebut juga diperlukan peningkatan kapasitas kepala desa dan aparat desa yang merupakan komponen utama di dalam penyelenggaraan desa, baik dalam hal perencanaan hingga pelaksanaan dan evaluasi, sehingga diharapkan dana yang ada di desa dapat terserap secara efektif dan efisien.

Kedua, permasalahan keterlambatan penyaluran dana desa yang terjadi karena alasan teknis seperti belum dikeluarkannya Peraturan Kepala Daerah perlu untuk segera diselesaikan. Perubahan kebijakan seperti transfer langsung dari RKUN ke RKD tanpa melewati RKUD sebagaimana yang telah dilakukan pada penyaluran dana BOS dapat menjadi opsi menarik untuk dilakukan. Dikotomi antara desa mandiri dan desa yang belum berstatus desa mandiri bisa jadi merupakan keputusan yang kontraproduktif. Pembangunan desa perlu untuk dipercepat tanpa harus dipusingkan dengan keperluan administratif dan birokrasi yang terlalu mengikat. Tahapan penyaluran dana desa yang hanya dua tahap seharusnya juga diberikan kepada desa yang belum berstatus desa mandiri untuk memberikan fleksibilitas lebih bagi desa dalam memanfaatkan dana desa secara lebih bermakna.

Ketiga, pemerintah dapat memperkuat kerjasama dengan perguruan tinggi dan lembaga swadaya masyarakat yang ada di daerah setempat untuk membantu desa mengoptimalkan dana yang ada agar mendorong pemberdayaan masyarakat serta pembangunan desa. Selain itu, penting untuk memberikan kepercayaan dan otonomi bagi desa dalam dalam mengelola dana desa sesuai ciri dan potensi tiap desa sebagaimana marwah dari UU Desa. Pemerintah perlu menanggalkan kebiasaan berfokus semata-mata terhadap tertib administrasi dan dapat mulai berfokus untuk memberikan porsi yang lebih besar bagi prioritas-prioritas yang ditentukan sendiri oleh desa.

\section{Ucapan Terima Kasih}

Penulis menghaturkan terima kasih yang sebesar-besarnya kepada keluarga dan rekan-rekan penulis yang telah mendukung terselesaikannya tulisan ini. Tak lupa juga Penulis berterima kasih kepada Kementerian Dalam Negeri dan tim editor atas kesempatannya untuk dapat menuangkan buah pikiran Penulis dalam Jurnal Matra Pembaruan. 


\section{Daftar Referensi}

Adji, A., Asmanto, P., \& Tuhiman, H. (2019). Reform on Village Fund Formulation. June. http://www.tnp2k. go.id/download/1986840WPVillagefundEngFinal.pdf

Aminah, S., \& Sutanto, H. P. (2018). Analisis Tingkat Kapasitas Aparatur Pemerintah Desa di Kabupaten Bogor. Matra Pembaruan, 2(3), 149-160. https://doi.org/10.21787/mp.2.3.2018.149-160

Antara. (2020). BNNP: 473 Kades Telah Terseret Korupsi Dana Desa. Mediaindonesia.Com. https:// mediaindonesia.com/politik-dan-hukum/292266/bnnp-473-kades-telah-terseret-korupsi-danadesa\#: : text=SEBANYAK 473 kepala desa se,dalam proses persidangan di pengadilan

Antlöv, H., Wetterberg, A., \& Dharmawan, L. (2016). Village Governance, Community Life, and the 2014 Village Law in Indonesia. Bulletin of Indonesian Economic Studies, 52(2), 161-183. https://doi.org/10. 1080/00074918.2015.1129047

Ardhi, I. (2018). Keterlambatan Implementasi Penyaluran Dana Desa. Jurnal Perbendaharaan, Keuangan Negara Dan Kebijakan Publik, 3(4), 330-346. https://itrev.kemenkeu.go.id/index.php/ITRev/article/ view/46/46

Asian Development Bank. (2016). Toward mainstreaming and sustaining community-driven development in Indonesia: understanding local initiatives and the transition from the national rural community empowerment program to the village law. http://www.adb.org/publications/toward-mainstreaming-andsustaining-cdd-indonesia

Badan Pusat Statistik. (n.d.). Jumlah Desa Kelurahan menurut Provinsi dan Letak Geografis. https://www. bps.go.id/dynamictable/2015/09/18 00:00:00/906/jumlah-desa-kelurahan-menurut-provinsi-danletak-geografi-2003---2018.html

Cahyono, H., Aziz, N. L. L., Nurhasim, M., Rahman, A. R., \& Zuhro, R. Si. (2020). Pengelolaan Dana Desa Studi dari Sisi Demokratis dan Kapasitas Pemerintahan Desa. In Proposal SIMLITAMAS. https://www. kemenkeu.go.id/media/6749/buku-pintar-dana-desa.pdf

Direktorat Jenderal Perimbangan Keuangan. (2021). Kebijakan-Dana-Desa-2021. http://www.djpk kemenkeu.go.id/wp-content/uploads/2021/02/Kebijakan-Dana-Desa-2021.pdf

Enggraini, F., Putri, N. C., Salman, Y. A., \& Handayani, W. (2020). Peran Kelembagaan Pemerintah Desa dalam Memajukan Desa Ponggok-Polanharjo, Klaten. Matra Pembaruan, 4(2), 71-82. https://doi. org/10.21787/mp.4.2.2020.71-82

Fajar, M., \& Achmad, Y. (2013). Dualisme Penelitian Hukum Normatif dan Empiris. Pustaka Pelajar. https:// opac.perpusnas.go.id/DetailOpac.aspx?id=717229

Harmadi, S. H. B., Suchaini, U., \& Adji, A. (2020). Village Development: Spatial Effect vs The Performance of the Village Government? February, 38. http://tnp2k.go.id/download/93404WP52ENGFinal2606.pdf

Herdiana, D. (2019). Kecenderungan Perilaku Koruptif Kepala Desa dalam Pembangunan Desa. Matra Pembaruan, 3(1), 1-11. https://doi.org/10.21787/mp.3.1.2019.1-11

Isti, I. (2019). Ombudsman : Banyak Masalah Terkait Dana Desa. https://www.ombudsman.go.id/artikel/r) artikel--ombudsman--banyak-masalah-terkait-dana-desa

Kartika, R. S. (2018). Manajerial Kepala Desa Taman Martani DIY dan Sukaraja Bandar Lampung Dalam Musyawarah Perencanaan Pembangunan (Musrenbang) Desa. Jurnal Matra Pembaruan, 1(Inovasi kebijakan), 59-69. https://doi.org/10.21787/mp.2.1.2018.59-69

Kementerian Dalam Negeri. (2018). Permendagri Nomor 20 Tahun 2018 tentang Pengelolaan Keuangan Desa. https://peraturan.bpk.go.id/Home/Details/139714/permendagri-no-20-tahun-2018

Kementerian Desa Pembangunan Daerah Tertinggal dan Transmigrasi. (n.d.). Penyaluran Dana Desa Tahun 2015 - 2019. Sistem Informasi Pembangunan Desa. http://sipede.ppmd.kemendesa.go.ic

Kementerian Desa Pembangunan Daerah Tertinggal dan Transmigrasi. (2020). Permendesa PDTT Nomor 13 Tahun 2020 tentang Prioritas Penggunaan Dana Desa Tahun 2021. https://peraturan.bpk.go.id/Home/ Details/151181/permendes-pdtt-no-13-tahun-2020

Kementerian Keuangan. (2020a). PMK Nomor 222/PMK.07/2020 tentang Pengelolaan Dana Desa. http:// www.djpk.kemenkeu.go.id/wp-content/uploads/2021/01/PMK-222_MK.07_2020_PengelolaanDana-Desa.pdf

Kementerian Keuangan. (2020b). PMK Nomor 9 Tahun 2020 tentang Perubahan atas PMK Nomor 48 Tahun 2019 tentang Pengelolaan DAK Non Fisik. http://www.djpk.kemenkeu.go.id/wp-content/ uploads/2020/02/PMK-No.-9-Th-2020.pdt

Kementerian Keuangan. (2020c). Salurkan Dana Bos Langsung ke Sekolah, Menkeu: Ini Bentuk Dukungan "Merdeka Belajar." https://www.kemenkeu.go.id/publikasi/berita/salurkan-dana-bos-langsung-kesekolah-menkeu-ini-bentuk-dukungan-merdeka-belajar

Kementerian Pendidikan dan Kebudayaan. (2020). Merdeka Belajar Episode Ketiga : Perubahan Mekanisme Bantuan Operasional Sekolah. Kemendikbud, 3. https://www.kemdikbud.go.id/main/files/download/ ff25dea7c772005

Khairullah, A. (2018). Indonesia's Village Fiscal Transfers Policy: Questioning The Village Government Competence. Ritsumei Journal, 14(December 2015), 1-14. http://www.ritsumei.ac.jp/research/rdiri/ file/kiyou/7-1.pdf

KOMPAK. (2016). Reality Check Approach Report : Local Perspectives and Experiences of the Village Law in Indonesia. http://www.reality-check-approach.com/uploads/6/0/8/2/60824721/vl_report_v11sm.pdf

KOMPAK, \& Bappenas. (2019). Catatan Kebijakan UU Desa: Pengelolaan, Pelaporan dan Pengawasan Keuangan Desa. https://www.kompak.or.id/id/download/273/catatan-kebijakan-uu-desa-pengelolaanpelaporan-dan-pengawasan-keuangan-desa.pdf

Kristianti, D. R. (2020). Gender Equality and Justice in the Indonesian Law on Village. 256-262. https://doi. org/10.5220/0010051602560262

Kushandajani, \& Alfirdaus, L. K. (2019). Women's Empowerment in Village Governance Transformation in 
Indonesia: Between Hope and Criticism. International Journal of Rural Management, 15(1), 137-157. https://doi.org/10.1177/0973005219836576

Luthfi, A., Rini, H. S., Gustaman, F. A., Arsal, T., \& Rochana, T. (2017). Partisipasi Masyarakat dalam Pengelolaan dan Pemanfaatan Dana Desa di Desa Keji Kabupaten Semarang. Matra Pembaruan, 1(2), 121-130. https://doi.org/10.21787/mp.1.2.2017.121-130

Muliawan, I., Sasmito, C., \& Gunawan, C. I. (2019). Implementasi Penyaluran Dana Desa di Kabupaten Sambas Kalimantan Barat. Jurnal Ilmu Administrasi: Media Pengembangan Ilmu Dan Praktek Administrasi, 16(1), 97-111. https://doi.org/10.31113/jia.v16i1.214

Pertana, P. R. (2019). Total Dana Desa sejak 2015 Capai 275 triliun. Detik.Com. https://finance.detik.com/ berita-ekonomi-bisnis/d-4483895/total-dana-desa-sejak-2015-capai-rp-275-triliun

Republik Indonesia. (2014). Undang-Undang Nomor 6 Tahun 2014 tentang Desa. https://peraturan.bpk. $\mathrm{go.id} /$ Home/Details/38582/uu-no-6-tahun-2014

Republik Indonesia. (2016). Peraturan Pemerintah Nomor 8 Tahun 2016 tentang Perubahan Kedua Peraturan Pemerintah Nomor 60 Tahun 2014 tentang Dana Desa yang bersumber dari APBN. https:// jdih.kemenkeu.go.id/fulltext/2016/8TAHUN2016PP.pdf

Salim, A., Bulan, W. R., Untung, B., Laksono, I., \& Brock, K. (2017). Indonesia's Village Law: enabler or constraint for more accountable governance? October, 20. https://core.ac.uk/download/pdf/286048288. pdf

Sedyadi, G. S. M., \& Isdijosi, W. (2017). SMERU Catatan Kebijakan : Memperlancar Penyaluran dan Pencairan Dana Desa. Seri UU Desa, 2(September), 4. http://smeru.or.id/id/content/mengefektifkan-pengawasandesa-oleh-masyarakat

Setiawan, F. X. H. (2018). Apa Kabar Dana Desa? Pajak.Go.Id. https://www. pajak.go.id/id/artikel/apa-kabardana-desa

Shiddiq, R. (2006). Antropologi Sosial. Pustaka Setia. http://www. pustakasetia.com/product/antropologikomunikasi/

Simorangkir, E. (2017). Pemerintah Kucurkan Dana Desa sejak 2015, Apa Saja Hasilnya? Detik.Com. https:// finance.detik.com/berita-ekonomi-bisnis/d-3606172/pemerintah-kucurkan-dana-desa-sejak-2015apa-saja-hasilnya

Soejamto. (1988). Daerah Istimewa dalam Kesatuan Negara Republik Indonesia. Bina Aksara. https:/l catalogue.nla.gov.au/Record/943820

Soekanto, S., \&Mahmudji, S. (2015). Penelitian HukumNormatif:SuatuTinjauanSingkat. RajawaliPress. https:// perpustakaan.mahkamahagung.go.id/slims/pusat/index.php?p=show_detail\&id=14461\&keywords=

Sofianto, A. (2017). Kontribusi Dana Desa terhadap Pembangunan dan Pemberdayaan Masyarakat di Kebumen dan Pekalongan. Matra Pembaruan, 1(1), 23-32. https://doi.org/10.21787/mp.1.1.2017.2332

Syukri, M., Bachtiar, P. P., Kurniawan, A., Sedyadi, G. S. M., Kartawijaya, Diningrat, R. A., \& Alifia, U. (2018). Studi Implementasi Undang-Undang No. 6 Tahun 2014 tentang Desa. In Laporan Penelitian SMERU (Issue 6). https://smeru.or.id/sites/default/files/publication/baselineuudesa.pdf

The World Bank. (2019). Indonesia - TA on Village Transfer: Policy Note on Redefining Village Expenditure Classification -Towards a Better Tracking of Village Spending (English). June, 46. http://documents. worldbank.org/curated/en/935921564028030541/Indonesia-TA-on-Village-Transfer-Policy-Noteon-Redefining-Village-Expenditure-Classification-Towards-a-Better-Tracking-of-Village-Spending

The World Bank. (2020). Indonesian Village Governance under the new Village Law (2015-2018). May. https://documents1.worldbank.org/curated/en/220661590726265687/pdf/Indonesian-VillageGovernance-Under-the-New-Village-Law-2015-2018-Sentinel-Villages-Report.pdf

Utami, A. F. (2017). Advancing Indonesia from the Margins: Implementing Public-Sector Strategic Management to Maximize the Impacts of Village Funds. https://scholar.google.com/citations?view_ op=view_citation\& $h l=e n \&$ user=SBT8JPQAAAAJ\&_citation_for_view=SBT8JPQAAAAJ:9yKSN -GCBOIC

Vel, J. A. C., \& Bedner, A. W. (2015). Decentralisation and village governance in Indonesia: The return to the nagari and the 2014 Village law. Journal of Legal Pluralism and Unofficial Law, 47(3), 493-507. https:/l doi.org/10.1080/07329113.2015.1109379

Vel, J., Zakaria, Y., \& Bedner, A. (2017). Law-Making as a Strategy for Change: Indonesia's New Village Law. Asian Journal of Law and Society, 4(2), 447-471. https://doi.org/10.1017/als.2017.21 